\title{
Tahar Ben Jelloun's La nuit de l'erreur
}

\author{
Mustapha Hamil \\ University of Illinois at Urbana-Champaign
}

M y primary interest in this study of Tahar Ben Jelloun's novel La nuit de l'erreur but, rather, to offer a symptomatic reading of the ideological location which makes it possible for Tahar Ben Jelloun to partake, equally, of the Maghrebian intellectual Diaspora and the disruptive narrative of postcoloniality. That the author wants his novels to be read as both postcolonial and diasporic is made visible enough in the main thematics he has repeatedly emphasized, whether in his novels or in his interviews or contributions to the French newspaper, Le Monde: the corruption of post-coloniality, Maghrebian migrants in France, sexuality and Islam, woman's condition and so on. The forms of narrativization, meanwhile, are diverse and belong, in nature, to a non-Western form of non-mimetic narration. They are mostly derived from an oral tradition, principally the Arabian Nights and the Halka, which generally exemplify the Arab penchant for obsessive digressions and the telling of an interminable story. French and Maghrebian critics' preoccupation with Ben Jelloun's formal 'avant-gardism' and postmodern narrative techniques has, though unintentionally, masked, as I will discuss shortly, his ideological and cultural (dis)location inside the Maghreb and Metropolitan France.

The crux of the narrative in La nuit de l'erreur is the main character, Zina, whose birth coincides with the death of her grandfather. This strange coincidence may have produced, in a different sort of trajectory and narrative, an appropriate metaphor for the way the idea of birth may generate a new chain of positive actions, especially after the death of one of the icons of patriarchal authority. Yet, the line of action that Zina chooses in order to assert herself in present-day Morocco is all too ambivalent. Ben Jelloun informs us that Zina was conceived during the Night of Error, during which Evil is supreme. Linking thus Zina's conception to the Night of Error calls her whole being into question, and what should normally have been a happy event becomes the source of all evils. Zina is, thus, from beginning a damned child and, as she will later define herself a"monster" (34). 
Like Salman Rushdie's Sufiya Zinobia in Shame, ${ }^{1}$ Zina is the link between the different narrative lines of the novel, and is at the center of that sense of dissatisfaction with her woman condition that breeds the all-enveloping violence directed against society as she finds it. If Zinobia's murderous character is attributed to her mental sickness, Zina's actions are attributed to her being conceived during the night of Error. Born under the stigma of a curse in a society already fraught with a pervasive sense of corruption, Zina is presented from the outset as the embodiment of redemption - if redemption is ever possible in Ben Jelloun's imagined world:

Je compris que $\mathrm{j}$ 'avais un don, celui de la clairvoyance extrême, celle qui nous met au contact avec l'air, l'eau et le feu. Je portais en moi assez de vertus pour agir sur le Mal, soit pour l'empêcher, soit pour l'utiliser contre ceux qui seraient injustes (33).

In the course of the novel, however, Zina's evil power takes over her 'clairvoyance' and 'virtues.' Its effects progressively shift from her immediate entourage and become increasingly directed against society as she moves into it. Ben Jelloun states over and over again that $Z$ ina is a victimized woman and that her victimization can produce only violence. Precisely, but violence in-itself-for-itself is not capable of regeneration, and its achievements are all but doubtful. Moreover, Zina's motives for vengeance are too equivocal: "Tes victimes sont des hommes...Tu subiras des violences et tu te vengeras...Ton besoin de destruction sera insatiable" (Your victims are men [...] You will be subjected to many forms of violence and you will revenge yourself [. . . Y Your need for destruction will be insatiable) (73). By reducing Zina's actions and reactions to vengeance, Ben Jelloun rules out the possibility that Zina could be capable of carrying out acts of social and political regeneration, or even of the sort of respectability and daily struggle of which many ordinary people are quite capable.

The very dialectic that governs the conceptual framework of the novel is, after all, incoherent. Ben Jelloun assigns to Zina a social conscience that simply contradicts the terms within which he has fashioned her own existence. The double punning in her name —on the Arabic word 'Beauty' and 'Adultery' - is, in context, excessive. And it is precisely from this excess that Zina suffers at the hands of her author. Unable to reconcile the opposing forces of Evil and Good in her, Zina deliberately chooses the track of destruction. The governing metaphor for her (re)actions-the Beast emerging from the inside the Beauty - belongs to the tradition of the Grotesque. One has simply to recall such legendary figures as Aisha Kendisha to have an idea where Ben Jelloun is driving at: "(Zina) est une femme qui a pactisé avec le Diable...Les enfants l'appellent Aisha Kendisha, mais pour être à la mode elle se fait appeler Zina" (Zina is a woman who has taken sides with the Devil [. . .] Children call her Aisha Kendisha, but in order to be modern, she calls herself Zina) (218).

The legendary figure of Aisha Kendisha provides a legitimizing background for the 
irrational manner in which Zina's destructive forces accumulate and for what she herself becomes (a destroyer of men) before she reaches her objective: vengeance against her rapists. Zina's first eruption occurs after the experience of 'La Nuit de L'Oubli' (68), when she concedes to a collective ritual of prohibited sexuality. The description of the scene is worth quoting at length:

En quelques minutes, nous nous retrouvâmes tous nus en train de forniquer comme des bêtes...ces hommes avaient l'habitude de forniquer en battant les femmes et en les injuriant...Il était imposible de fuir. J'enregistrai leurs voix dans ma tête. Cela était peut-être suffisant pour les retrouver un jour (65).

The disturbing element in the passage is, as it were, the return of the image of the Arab woman and man as a 'beast' and a sexual maniac. ${ }^{2}$ Doubtlessly, such a detailed description of the sexual carnival conforms to the many discursive constructions and ideologies in which the Moroccan (Arab) has been represented in Orientalist writing. The choice of the cave and the presence of an Australian woman among the group of Moroccans add to the 'exotic' pigment of the scene which takes place, as one may expect, in Tangiers.

In almost every novel he writes, Ben Jelloun uses his literary skills to induce uninitiated readers to believe, naively, the exotic pastiche that accompanies descriptions of Moroccans and Arabs. His first novel, Harrouda (1973), is dedicated to his mother, to whom he wants to lend his voice and text. But Harrouda is also an anthropologic symbol of a woman whom popular imagination has marginalized. The first chapter of the novel is entitled "Interview with my mother." Curiously enough, the mother's words can be heard only through Harrouda's voice. Not only does such a discursive rearrangement of voices deprive the mother of her own words, it also dispossesses her of her identity.

If in Civilisation ma mère and qui se souvient de la mer?, Chraibi and Dib use French as a means of liberation, Ben Jelloun uses it in order to imprison his women within a mode of representation where they speak a language which is not theirs. His recent novels, including L'Auberge des pauvres (1999), seem to deal with a culture where the only visible impacts of French rule are the acquisition of the French language and Francophone writers' access to a French audience. In fact, Ben Jelloun's later stories belong to a discourse on Moroccan and Arab degradation that present and represent the most backward elements of Moroccan culture almost irreversible. Incest, prostitution, rape, sodomy, and even female circumcision proliferate in these stories.

If Harrouda finds some temporary solace among 'her' children of the streets, who give her tangerines and sleep between her legs (15), Zina turns into a vicious woman who decides to avenge herself against the five men who presumably 'raped' her. With her female companions, Houda, Zineb, Kenza, Batoule, she plots against her five men, Salim, Abid, Carlos, Bechar, and Bilal. To each one of them, she assigns one of her protégées. Zina's strategy is very simple: she picks up her man, makes him fall in love with her, 
tortures him, and then destroys his manliness. Within the immediate confines of the novel, Zina becomes the embodiment of a misogynist myth: the 'virgin' who is really a femme fatale, the irresistible Aisha Kandisha who seduces men in order to kill them. She is no longer an object of male manipulation or idolization but a 'devourer' of men. Her power is that of a 'sorceress,' the woman-beast dear to exotic literature. In discovering her 'hidden' female power - or at least the 'power' Ben Jelloun provides for her, Zina becomes the opposite not only of the veiled Arab woman, but also the opposite of the Muslim male who may marry one, two, three, or four women. Yet the powers that Ben Jelloun attributes to her do not ensure any concrete or lasting power on her part: sorceress or saint implies a distancing of the author - and the reader - from any belief in the woman's abilities to affect radical change around her. It is true that Zina draws her men inside her proper terrain in order to enslave, and eventually destroy them. But what Ben Jelloun does not seem to realize in this game of power is that her scheme, despite its superficial success, involves a certain ambiguity by which the woman/victim can exercise control over her victimizer - and thus elicit the reader's admiration - almost by virtue of her victimization or auto-victimization. The result is the repetition of the same story, dominated by the image of the hand with five fingers, each one a different story of insatiable destruction. Repetition functions here as a hypnotic strategy by means of which Ben Jelloun captivates his readers' imagination. In all five versions of the same story, Zina appears determined and self-confident. Ironically, the only power she is capable of exerting is that of destruction: "Fille de Satan, elle est le Mal qui court et menace la paix du pays." [Daughter of Satan, she is Evil that runs and threatens the peace of the country] (104).

The figure of the 'sorceress' suggests an element of complicity between subject and object: while dominating her men, Zina remains nonetheless an object of their sexual desire. On the level of what is explicitly stated in the novel, Zina succeeds in seducing her men precisely because they desire her and thus make themselves subservient to her demands. On the level of discourse analysis, one cannot ignore the reductive connotations of such descriptions as 'sorcière,' 'fleur carnivore,' 'tigrèsse.' All of these terms point to the clichéd image of the femme fatale. And Zina is presented as one.

Moreover, Zina's indeterminate subject positions in the novel - 'sorceress,' saint - the flavor of the exotic, the quasi pornographic language of the novel situate Zina's transgressive acts within an imaginary world that is closer to fantastic accounts than to that of present-day North Africa. In fact, La nuit de l'erreur is replete with exorbitant descriptions of sexuality, male and female genitalia, semen, urine, and filth. If the Arabophone writers, Mohamed Choukri and Mohamed Zefzaf deploy sexual imagery in their novels, they do so as a gesture of revolt against the repressive sexual education of society. Ben Jelloun does it in order to imbed the problem of his cultural dislocation in the ambiguous condition of postcoloniality.

What is not overtly stated in the novel is that Zina and her female companions, despite their indulgence in unfettered sexuality, are caught within a sexual configuration in which they are made to reproduce the traditional structures of patriarchy. Zina's initial 
scheme involves revenge against her five men, the inversion of the traditional male-female hierarchy, and, concomitantly, the liberation of her body. Through her, Ben Jelloun seeks to displace the institutionalized male-female opposition. But considering the choices made available for Zina, her subsequent actions may be reduced to one slogan: "I am Woman, Watch me Destroy." Gayatri Spivak has argued that "the displacement of male-female, public-private marks a shifting limit rather than the desire for a complete reversal. ${ }^{\prime 3}$ In $\mathrm{La}$ nuit de l'erreur, however, Ben Jelloun allows Zina a limited range of freedom to carry out her destructive scheme in so far as she does not question the social and cultural apparatus of her condition. He seems to suggest, in other words, that the male-female asymmetrical relationship must remain the same, repressive and patriarchal, allowing, at most, for the possibility that an unusual woman can revolt from time to time. Undoubtedly, such individual revolts, which are devoid of a clear vision of what one revolts against, only serve to naturalize existing economic, legal, and political inequality. And instead of imposing difference and respect, they only inspire indifference and contempt.

Instead of deconstructing the cultural and ideological discourses by means of which women are socially and legally defined in the Arab world, Ben Jelloun claims over and over again that Zina's indulgence in prohibited sexuality and counter-violence is emblematic of (her) social emancipation. True, but as long as this emancipation bears no immediate effect on others, the claim itself remains empty and unproductive. Throughout the novel, one has the impression that Zina's body exists outside the cultural and social regulations by which it is initially constituted, veiled, and repressed. Nowhere in the novel does Ben Jelloun attempt to interrogate the historical and ideological relevance of these regulations or to provide radical questioning of the theocentric discourse that informs them. Moreover, he excludes from his vision that apparent polar male-female opposites may in fact be interchangeable and mutually interdependent. From beginning to end, Zina uses her beauty to attract and then demolish her men simply because they are men. Nowhere in the novel does she attempt to understand why these men act as they do. Her counter-attacks convey however one significant certitude: Ben Jelloun's inability to conceive of her heroine outside the male-female dialectics.

Ben Jelloun has stressed on many occasions the importance of women in fiction and in society. Yet here he seems to have forgotten his previous positions and thus fashioned in La Nuit de l'erreur a macabre caricature of what female resistance to phallocentric mentality might be. Zina, the woman, becomes, in this version of resistance, a rapist, a criminal, and a hypocrite "Cherifa" or Saint. Given the fact that social change is a product of historical determinism, Ben Jelloun appears unable to envision a real possibility of regenerative projects on the part of the people who actually exist within our contemporary society. And even when he attempts to open up a regenerative possibility, the powers that he bestows on his female protagonist in the brief moments of her triumphs are powers of destruction. His failure to think of more convincing local strategies of woman's resistance in post-colonial Morocco is not hard to explain. First, Ben Jelloun looks at his society from within a horizon of expectation that is irrelevant to the Moroccan context. Second, his 
cultural dislocation makes him see Moroccan culture as stable and unchanging. It is not only by giving Arab names to objects and people that one can aspire to be the spokesperson of his/her culture. In La Nuit de l'erreur, however, the voice that we hear is not that of Zina, but that of Ben Jelloun speaking to himself. The intertextual references to his previous works, Harrouda, Moha le fou, Moha le sage place Zina's story in his personal literary repertoire rather than in the stream of contemporary reality.

\section{Notes}

${ }^{1}$ Ben Jelloun makes a reference to this novel as one of his favorite. In La Nuit de l'erreur, he writes a letter to Rushdie in which he praises him for his audacious positions.

2 In Orientalism, (1987) Edward Said provides a succinct and detailed account of the Orientalist ideology informing the construction of the Other in terms of sexual degradation and degeneracy. See also David Spurr, The Rhetoric of Empire, op.cit.

${ }^{3}$ Gayatri Spivak, In Other Worlds: Essays in Cultural Politics (New York: Methuen, 1987) 103. 